\title{
Prevalence and associated factors of uncontrolled hypertension among hypertensive patients: a nation-wide survey in Thailand
}

\author{
Boonsub Sakboonyarat ${ }^{{ }^{*}}\left(\mathbb{D}\right.$, Ram Rangsin ${ }^{1}$, Anupong Kantiwong ${ }^{2}$ and Mathirut Mungthin ${ }^{2}$
}

\begin{abstract}
Objectives: The objectives of the research were to determine the prevalence and factors associated of uncontrolled blood pressure among Thai hypertensive patients in a nationwide survey.

Results: A total of 65,667 patients with hypertension were included in this study. The greater proportion of participants, 40,834 (62.2\%), were females. The average age of participants was 63.9 11.1 years. Uncontrolled hypertension was detected among 16,122 patients $(24.6 \% ; 95 \%$ Cl 24.2-24.9). Among males and females, uncontrolled hypertension was $25.6 \%(95 \% \mathrm{Cl} 25.1-26.2)$ and $23.9 \%(95 \% \mathrm{Cl} 23.5-24.3)$ respectively. Multivariate analysis showed that the uncontrolled hypertension was significantly associated with being male, age, regions, hospital levels, diabetes comorbidity, higher body mass index, low density lipoprotein cholesterol level and the number of antihypertensive medications.
\end{abstract}

Keywords: Uncontrolled hypertension, Prevalence, Associated factors, Nationwide, Thailand

\section{Introduction}

Hypertension is one of the most common cardiovascular disorders worldwide. Globally, 30.8\% of adults have hypertension, and the estimated prevalence of hypertension among males and females is $32.1 \%$ and $29.5 \%$, respectively [1]. Hypertension is a major modifiable risk factor for heart diseases, stroke, end stage renal failure and peripheral vascular disease. The Thai National Health Examination Survey (NHES) 2004 and the NHES 2009 data indicated that it affects nearly one in every five Thai adults [2]. Information on controlling blood pressure (BP) is available worldwide, and the prevalence of controlled BP reported in the US, UK, China and Japan were $68.9 \%, 60.8 \%, 37.5 \%$ and $37.1 \%$, respectively $[1,3]$. However, limited information is available regarding the prevalence of uncontrolled hypertension in Thailand especially

\footnotetext{
*Correspondence: boonsub1991@pcm.ac.th

${ }^{1}$ Department of Military and Community Medicine, Phramongkutklao College of Medicine, Bangkok 10400, Thailand

Full list of author information is available at the end of the article
}

in nationwide studies. We aimed to use the information from the Thailand Diabetes Mellitus/Hypertension (DM/ HT) of the Medical Research Network of the Consortium of Thai Medical Schools (MedResNet) to determine BP control and risk factors associated with uncontrolled BP among Thai hypertensive patients from 2014 to 2015.

\section{Main text Methods}

A nationwide, cross-sectional survey was conducted from 2014 to 2015 . The survey aimed to determine outcomes among patients with hypertension visiting clinics in Bangkok supported by the Thailand National Health Security Office's (NHSO) program, private hospitals and public hospitals of the Ministry of Public Health (MoPH) in Thailand.

This study was reviewed and approved by the Royal Thai Army Medical Department and local institutional review boards of the participating hospitals. For selecting national representative samples of patients with hypertension in Thailand, a stratified two-stage cluster 
sampling method proportional to the size was conducted. For Bangkok, the targeted hospitals included all hospitals and clinics under the NHSO. However, all university hospitals were excluded.

Hypertensive patients aged $\geq 18$ years receiving medical treatment in a hospital, drawn from those sampling methods, during the previous 1 year were included. Any patient who had participated in a clinical trial was excluded. The number of participants totaled 65,667 . The number of hospitals under the MoPH totaled 833 hospitals, including 717 community hospitals, 83 general hospitals and 33 regional hospitals. Hypertensive patients were selected by sampling and registered at each hospital. A standardized case report form was used to collect data from medical records of hypertensive treatment and was sent to the central data management unit. The data, including status of hypertensive complications and results of laboratory tests, were retrieved from patient's medical records.

Hypertension was defined by JNC's eight hypertension guidelines as high $\mathrm{BP}(\mathrm{SBP} \geq 140 \mathrm{mmHg}$ or $\mathrm{DBP} \geq 90 \mathrm{mmHg}$ ) and/or use of antihypertensive medicine [4]. Uncontrolled hypertension was defined by JNC's eight hypertension guidelines. The BP target is $\mathrm{SBP}<140 \mathrm{mmHg}$ or $\mathrm{DBP}<90 \mathrm{mmHg}$ among adults younger than 60 years and a $\mathrm{BP}$ goal of $\mathrm{SBP}<150 \mathrm{mmHg}$ and $\mathrm{DBP}<90 \mathrm{mmHg}$ in the general population aged $\geq 60$ years [4]. BMI was calculated as body weight in kilograms (kg) divided by height in meters squared [weight $(\mathrm{kg}) /$ height $(\mathrm{m})^{2}$ ]. Waist circumferences were measure at the level of the umbilicus [5].

Data were coded, entered and analyzed using IBM SPSS Statistics for Windows, Version 23.0. Categorical data were presented as number and percentage, while continuous data were presented as mean and standard deviation (SD). Prevalence was analyzed using descriptive statistics and reported as percentage and 95\% confidence interval. The Chi-square test was used to compare categorical data, while continuous data were compared using the $t$-test. The magnitude of association was presented as crude odds ratios (ORs) with 95\% confidence interval. The final model with multivariate logistic regression analysis was created. A $p$-value $<0.05$ was considered statistically significant.

\section{Results}

A total of 65,667 Thai patients with hypertension were enrolled in this study. The greater proportion of participants, 40,834 (62.2\%), were females (Table 1). The average age of participants was $63.9 \pm 11.7$ years, while the average duration of hypertension was $6.5 \pm 4.1$ years. The average SBP was $133.6 \pm 15.2 \mathrm{mmHg}$ while the average DBP was $75.9 \pm 10.6 \mathrm{mmHg}$. Overall prevalence of
Table 1 Demographic characteristics of the enrolled Thai adults with hypertension

\begin{tabular}{|c|c|}
\hline Variables & n (\%) \\
\hline \multicolumn{2}{|l|}{ Gender } \\
\hline Female & $40,834(62.2)$ \\
\hline Male & $24,833(37.8)$ \\
\hline Age (years) (mean $\pm S D$ ) & $63.9 \pm 11.7$ \\
\hline $20-29$ & $98(0.1)$ \\
\hline $30-39$ & $1077(1.6)$ \\
\hline $40-49$ & $6383(9.7)$ \\
\hline $50-59$ & $16,276(24.8)$ \\
\hline $60-69$ & $19,966(30.4)$ \\
\hline $70-79$ & $15,511(23.6)$ \\
\hline $80-89$ & $5832(8.9)$ \\
\hline$\geq 90$ & $456(0.7)$ \\
\hline \multicolumn{2}{|l|}{ Region, n (\%) } \\
\hline Northeast & $14,864(22.6)$ \\
\hline Northern & $18,032(27.5)$ \\
\hline Central & $23,104(35.2)$ \\
\hline Southern & $9667(14.7)$ \\
\hline \multicolumn{2}{|l|}{ Hospital level } \\
\hline First level & $45,541(69.4)$ \\
\hline Middle level & $15,030(22.9)$ \\
\hline Standard/Advance level & $5096(7.8)$ \\
\hline \multicolumn{2}{|l|}{ Healthcare coverage } \\
\hline Universal coverage scheme & $48,747(74.2)$ \\
\hline Government officer & $13,181(20.1)$ \\
\hline Social security scheme & $2931(4.5)$ \\
\hline Others & $808(1.2)$ \\
\hline \multicolumn{2}{|l|}{ Occupations } \\
\hline Unemployed/retired & $22,438(34.2)$ \\
\hline Agriculturist & $3346(5.1)$ \\
\hline Private business & $22,649(34.5)$ \\
\hline Officer & $3820(5.8)$ \\
\hline Others & $13,414(20.4)$ \\
\hline \multicolumn{2}{|l|}{ Comorbidity } \\
\hline Dyslipidemia & $41,171(62.7)$ \\
\hline Diabetes mellitus & $8628(13.1)$ \\
\hline Gout & $5083(7.7)$ \\
\hline \multicolumn{2}{|l|}{ Smoking } \\
\hline Never & $50,733(82.6)$ \\
\hline Ex-smoker & $7624(12.4)$ \\
\hline Current smoker & $3035(4.9)$ \\
\hline Duration of hypertension (years) (mean $\pm S D$ ) & $6.5 \pm 4.1$ \\
\hline \multicolumn{2}{|l|}{ Blood pressure $(\mathrm{mmHg})$} \\
\hline $\mathrm{SBP}($ mean $\pm \mathrm{SD})$ & $132.6 \pm 15.2$ \\
\hline $\mathrm{DBP}($ mean $\pm \mathrm{SD})$ & $75.9 \pm 10.6$ \\
\hline Waist circumference (cm) & $86.3 \pm 10.8$ \\
\hline $\mathrm{BMI}\left(\mathrm{kg} / \mathrm{m}^{2}\right)($ mean $\pm \mathrm{SD})$ & $24.9 \pm 4.7$ \\
\hline$<25$ & $34,137(54.1)$ \\
\hline $25-29.99$ & $20,797(33)$ \\
\hline $30-34.99$ & $6386(10.1)$ \\
\hline$\geq 35$ & $1751(2.8)$ \\
\hline
\end{tabular}


Table 1 (continued)

\begin{tabular}{ll}
\hline Variables & $\mathbf{n}(\%)$ \\
\hline Biochemical measurements (mean \pm SD) & \\
Serum uric acid (mg/dL) & $6.1 \pm 1.8$ \\
TC (mg/dL) & $193.7 \pm 44.7$ \\
TG (mg/dL) & $150.9 \pm 89.2$ \\
HDL (mg/dL) & $50.7 \pm 15.6$ \\
LDL (mg/dL) & $115.1 \pm 36.8$ \\
Estimated GFR (mL/min/1.73 m $\left.^{2}\right)$ & $71 \pm 23.6$ \\
$\geq 90$ & $13,678(23.7)$ \\
$60-89$ & $25,263(43.8)$ \\
$30-59$ & $16,418(28.4)$ \\
$15-29$ & $1649(2.9)$ \\
$<15$ & $731(1.3)$ \\
Number of antihypertensive medications & \\
0 & $1110(1.7)$ \\
1 & $26,153(39.8)$ \\
2 & $27,175(41.4)$ \\
$\geq 3$ & $11,229(17.1)$ \\
\hline
\end{tabular}

$S D$ standard deviation, $\mathrm{mmHg}$ millimeter of mercury, $S B P$ systolic blood pressure, $D B P$ diastolic blood pressure, $\mathrm{Cm}$ centimeter, $F P G$ fasting plasma glucose, $T C$ total cholesterol, TG triglyceride, HDL, high-density lipoprotein cholesterol, LDL low-density lipoprotein cholesterol, BMI body mass index, eGFR estimated glomerulus filtration rate

uncontrolled hypertension in the study was $24.6 \%$ (95\% CI 24.2-24.9). Among males and females, uncontrolled hypertension was $25.6 \%$ (95\% CI 25.1-26.2) and $23.9 \%$ (95\% CI 23.5-24.3), respectively. Univariate and multivariate analysis were performed to determine factors associated with uncontrolled hypertension (Tables 2 and 3 ). The final model was adjusted for sex, age, regions, hospital levels, smoking, diabetes mellitus (DM) comorbidity, duration of hypertension, BMI, LDL level and the number of antihypertensive medications used. After adjusting, the factors associated with uncontrolled hypertension comprised being male, regions, hospital levels, DM comorbidity, higher BMI, higher LDL level and higher number of antihypertensive medications used; however, higher age was a protective factor for uncontrolled hypertension.

\section{Discussion}

These results revealed important implications to the Thai public health system because hypertension is a major risk factor for cerebrovascular events and cardiovascular diseases. A secondary intervention is necessary to reduce any complications. This study comprised the largest research in Southeast Asia, focusing on uncontrolled hypertension. The present nationwide survey from 2014 to 2015 showing the prevalence of uncontrolled hypertension among Thai adults with hypertension was $24.6 \%$.
The prevalence of uncontrolled hypertension in the current study was lower than that previously reported for US and China $[6,7]$. However, in Thailand one related study in 2009 reported the prevalence of uncontrolled hypertension was $75.6 \%$ [2]. Thus, in the present study, the prevalence of uncontrolled hypertension was lower than that in the 2009 survey. This situation could be explained by several points. Firstly, the related study [2] was conducted by a national health examination in a field survey while the present study was conducted among hypertensive patients receiving medical treatment in a hospital. In 2012, Thai guidelines on treating hypertension were released to direct any physician including general practitioners and specialists. Therefore, Thai patients with hypertension have been receiving appropriate medical treatment. Consequently, patients with hypertension, who follow-up with their physicians, have obtained more proper medical care. In the present study, patients with hypertension obtaining medical treatment in hospitals under the MoPH all over Thailand were enrolled. However, those with high BP treated at primary care units or university hospitals were not included in the current study; thus, the prevalence of uncontrolled hypertension may be underestimated.

The present study showed that patients with hypertension at higher ages tended to be at lower risk for uncontrolled hypertension, similar to other studies [7, 8]. Hypertensive complications and end organ damage will not occur in the early period of hypertension. Thus, younger hypertensive patients lack awareness of complications; moreover, working age people may not follow up their appointment with medical doctors resulting from the available time mismatch between working age patients and healthcare services [9]. However, some studies have shown that the prevalence of uncontrolled hypertension among elderly hypertensive patients was more likely to be higher [10-12]. Similarly, some related studies conducted in the US and China revealed that males had a higher risk for uncontrolled hypertension than females [10,13-15] due to biological factors [16] including hormonal effects on increased BP. These related studies have shown that females have lower prorenin and renin levels than males, causing BP among males to be higher than females $[16,17]$. Nevertheless, another study reported hypertension could be better controlled among males [18].

Our findings showed that the prevalence of uncontrolled hypertension differed by region. In the northeast area, the prevalence of uncontrolled hypertension was significantly lower than that in other regions. The finding could be explained by behavioral and local cultural factors. Patients in this area enjoyed consuming vegetable and fruits, which may have decreased body adiposity 
Table 2 Univariate analysis for factors associated with uncontrolled hypertension among Thai adults with hypertension

\begin{tabular}{|c|c|c|c|c|c|}
\hline Variables & $\begin{array}{l}\text { Normotension } \\
\text { n (\%) }\end{array}$ & $\begin{array}{l}\text { Uncontrolled HT } \\
\text { n (\%) }\end{array}$ & $\begin{array}{l}\text { Crude } \\
\text { Odds ratio }\end{array}$ & $95 \% \mathrm{Cl}$ & $p$-value \\
\hline \multicolumn{6}{|l|}{ Gender } \\
\hline Female & $31,077(76.1)$ & 9757 (23.9) & 1 & & \\
\hline Male & $18,468(74.4)$ & $6365(25.6)$ & 1.10 & $(1.06-1.14)$ & $<0.001$ \\
\hline Age (years) & $64.9 \pm 11.4$ & $60.7 \pm 12.2$ & 0.97 & $(0.97-0.97)$ & $<0.001$ \\
\hline $20-29$ & $48(49.0)$ & $50(51.0)$ & 1 & & \\
\hline $30-39$ & $625(58.0)$ & $452(42.0)$ & 0.69 & $(0.46-1.05)$ & 0.084 \\
\hline $40-49$ & 4064 (63.7) & $2319(36.3)$ & 0.55 & $(0.37-0.82)$ & 0.003 \\
\hline $50-59$ & 10,811 (66.4) & 5465 (33.6) & 0.49 & $(0.33-0.72)$ & $<0.001$ \\
\hline $60-69$ & $16,251(81.4)$ & 3715 (18.6) & 0.22 & $(0.15-0.33)$ & $<0.001$ \\
\hline $70-79$ & $12,613(81.3)$ & 2898 (18.7) & 0.22 & $(0.15-0.33)$ & $<0.001$ \\
\hline $80-89$ & $4697(80.5)$ & 1135 (19.5) & 0.23 & $(0.16-0.35)$ & $<0.001$ \\
\hline$\geq 90$ & $384(84.2)$ & $72(15.8)$ & 0.18 & $(0.11-0.29)$ & $<0.001$ \\
\hline \multicolumn{6}{|l|}{ Region } \\
\hline Northeast & $11,813(79.5)$ & 3051 (20.5) & 1 & & \\
\hline Northern & $13,717(76.1)$ & 4315 (23.9) & 1.22 & $(1.16-1.28)$ & $<0.001$ \\
\hline Central & $17,101(74.0)$ & $6003(26.0)$ & 1.36 & $(1.29-1.43)$ & $<0.001$ \\
\hline Southern & $6914(71.5)$ & $2753(28.5)$ & 1.54 & $(1.45-1.64)$ & $<0.001$ \\
\hline \multicolumn{6}{|l|}{ Hospital level } \\
\hline First level & $35,160(77.2)$ & 10,381 (22.8) & 1 & & \\
\hline Middle level & $10,668(71.0)$ & $4362(29.0)$ & 1.39 & $(1.33-1.44)$ & $<0.001$ \\
\hline Standard/advance level & $3717(72.9)$ & $1379(27.1)$ & 1.26 & $(1.18-1.34)$ & $<0.001$ \\
\hline \multicolumn{6}{|l|}{ Healthcare coverage } \\
\hline Universal coverage scheme & $36,881(75.7)$ & $11,866(24.3)$ & 1 & & \\
\hline Government officer & $10,193(77.3)$ & $2988(22.7)$ & 0.91 & $(0.87-0.95)$ & $<0.001$ \\
\hline Social security scheme & $1903(64.9)$ & $1028(35.1)$ & 1.68 & $(1.55-1.82)$ & $<0.001$ \\
\hline Others & $568(70.3)$ & $240(29.7)$ & 1.31 & $(1.13-1.53)$ & $<0.001$ \\
\hline \multicolumn{6}{|l|}{ Occupations } \\
\hline Unemployed/retired & $17,809(79.4)$ & $4629(20.6)$ & 1 & & \\
\hline Agriculturist & $2387(71.3)$ & $959(28.7)$ & 1.55 & $(1.43-1.68)$ & $<0.001$ \\
\hline Private business & $17,266(76.2)$ & $5383(23.8)$ & 1.20 & $(1.15-1.25)$ & $<0.001$ \\
\hline Officer & $2706(70.8)$ & $1114(29.2)$ & 1.58 & $(1.47-1.71)$ & $<0.001$ \\
\hline Others & $9377(69.9)$ & $4037(30.1)$ & 1.66 & $(1.58-1.74)$ & $<0.001$ \\
\hline \multicolumn{6}{|l|}{ Dyslipidemia } \\
\hline No & $18,345(74.9)$ & $6151(25.1)$ & 1 & & \\
\hline Yes & $31,200(75.8)$ & $9971(24.2)$ & 0.95 & $(0.92-0.99)$ & 0.010 \\
\hline \multicolumn{6}{|l|}{ Diabetes mellitus } \\
\hline No & $43,311(75.9)$ & $13,728(24.1)$ & 1 & & \\
\hline Yes & $6234(72.3)$ & $2394(27.7)$ & 1.21 & $(1.15-1.28)$ & $<0.001$ \\
\hline \multicolumn{6}{|l|}{ Gout } \\
\hline No & $45,755(75.5)$ & $14,829(24.5)$ & 1 & & \\
\hline Yes & $3790(74.6)$ & $1293(25.4)$ & 1.05 & $(0.99-1.12)$ & 0.126 \\
\hline \multicolumn{6}{|l|}{ Smoking } \\
\hline Never & $38,552(76.0)$ & $12,181(24.0)$ & 1 & & \\
\hline Ex-smoker & $5801(76.1)$ & $1823(23.9)$ & 0.99 & $(0.94-1.05)$ & 0.851 \\
\hline Current smoker & $2202(72.6)$ & $833(27.4)$ & 1.20 & $(1.10-1.30)$ & $<0.001$ \\
\hline Duration of hypertension (years) & $6.6 \pm 4.1$ & $6.4 \pm 4.0$ & 0.99 & $(0.98-0.99)$ & $<0.001$ \\
\hline Waist circumference $(\mathrm{cm})$ & $85.8 \pm 10.6$ & $87.8 \pm 11.1$ & 1.02 & $(1.01-1.02)$ & $<0.001$ \\
\hline $\mathrm{BMI}\left(\mathrm{kg} / \mathrm{m}^{2}\right)$ & $24.6 \pm 4.5$ & $25.9 \pm 4.9$ & 1.06 & $(1.06-1.06)$ & $<0.001$ \\
\hline
\end{tabular}


Table 2 (continued)

\begin{tabular}{|c|c|c|c|c|c|}
\hline Variables & $\begin{array}{l}\text { Normotension } \\
\text { n (\%) }\end{array}$ & $\begin{array}{l}\text { Uncontrolled HT } \\
\mathrm{n}(\%)\end{array}$ & $\begin{array}{l}\text { Crude } \\
\text { Odds ratio }\end{array}$ & $95 \% \mathrm{Cl}$ & $p$-value \\
\hline$<25$ & $27,156(79.6)$ & $6981(20.4)$ & 1 & & \\
\hline $25-29.99$ & $15,227(73.2)$ & $5570(26.8)$ & 1.42 & $(1.37-1.48)$ & $<0.001$ \\
\hline $30-34.99$ & $4309(67.5)$ & 2077 (32.5) & 1.88 & $(1.77-1.99)$ & $<0.001$ \\
\hline$\geq 35$ & $1048(59.9)$ & $703(40.1)$ & 2.61 & $(2.36-2.88)$ & $<0.001$ \\
\hline \multicolumn{6}{|l|}{ Biochemical measurements } \\
\hline Serum uric acid (mg/dL) & $6.1 \pm 1.8$ & $6.2 \pm 1.9$ & 1.04 & $(1.03-1.06)$ & $<0.001$ \\
\hline $\mathrm{TC}(\mathrm{mg} / \mathrm{dL})$ & $192.3 \pm 43.1$ & $198.1 \pm 49.0$ & 1.01 & $(1.00-1.01)$ & $<0.001$ \\
\hline $\mathrm{TG}(\mathrm{mg} / \mathrm{dL})$ & $148.8 \pm 87.3$ & $157.5 \pm 94.6$ & 1.01 & $(1.00-1.01)$ & $<0.001$ \\
\hline $\mathrm{HDL}(\mathrm{mg} / \mathrm{dL})$ & $50.7 \pm 15.8$ & $50.8 \pm 15.2$ & 1.01 & $(1.00-1.01)$ & 0.467 \\
\hline $\mathrm{LDL}(\mathrm{mg} / \mathrm{dL})$ & $114.0 \pm 36.4$ & $118.5 \pm 38.1$ & 1.01 & $(1.00-1.01)$ & $<0.001$ \\
\hline Estimated GFR (mL/min/1.73 m²) & $70.2 \pm 23.2$ & $73.7 \pm 24.7$ & 1.01 & $(1.00-1.01)$ & $<0.001$ \\
\hline$\geq 90$ & $9732(71.2)$ & $3946(28.8)$ & 1 & & \\
\hline $60-89$ & $19,314(76.5)$ & $5949(23.5)$ & 0.76 & $(0.73-0.80)$ & $<0.001$ \\
\hline $30-59$ & $12,974(79.0)$ & $3444(21.0)$ & 0.66 & $(0.62-0.69)$ & $<0.001$ \\
\hline $15-29$ & $1274(77.3)$ & $375(22.7)$ & 0.73 & $(0.64-0.82)$ & $<0.001$ \\
\hline$<15$ & $511(69.9)$ & $220(30.1)$ & 1.06 & $(0.90-1.25)$ & 0.469 \\
\hline \multicolumn{6}{|c|}{ Number of antihypertensive medications } \\
\hline 0 & $930(83.8)$ & $180(16.2)$ & 1 & & \\
\hline 1 & $20,717(79.2)$ & $5436(20.8)$ & 1.36 & $(1.15-1.60)$ & $<0.001$ \\
\hline 2 & $20,148(74.1)$ & $7027(25.9)$ & 1.80 & $(1.53-2.12)$ & $<0.001$ \\
\hline$\geq 3$ & $7750(69.0)$ & $3479(31.0)$ & 2.32 & $(1.97-2.73)$ & $<0.001$ \\
\hline \multicolumn{6}{|l|}{ Drug classes (monotherapy) } \\
\hline ARB & $1953(76.6)$ & $595(23.4)$ & 1 & & \\
\hline ACEl & $5520(77.1)$ & $1644(22.9)$ & 0.98 & $(0.88-1.09)$ & 0.678 \\
\hline Anti-adrenergic & $2060(78.4)$ & $566(21.6)$ & 0.90 & $(0.79-1.03)$ & 0.121 \\
\hline Diuretics & 2697 (80.9) & 635 (19.1) & 0.77 & $(0.68-0.88)$ & $<0.001$ \\
\hline CCBs & 8301 (81.2) & $1921(18.8)$ & 0.76 & $(0.68-0.84)$ & $<0.001$ \\
\hline
\end{tabular}

SD standard deviation, $\mathrm{mmHg}$ millimeter of mercury, SBP systolic blood pressure, DBP diastolic blood pressure, $\mathrm{cm}$ centimeter, $F P G$ fasting plasma glucose, $T C$ total cholesterol, $T G$ triglyceride, $H D L$, high-density lipoprotein cholesterol, $L D L$ low-density lipoprotein cholesterol, $B M I$ body mass index, eGFR estimated glomerulus filtration rate, $A R B$ angiotensin receptor blockers, $A C E l$ angiotensin converting enzyme inhibitors; anti-adrenergic; alpha and beta blockers, $C C B s$, calcium channel blockers

levels, consequently reducing BP [19-21]. Nevertheless, after adjusting, both residing in northeast Thailand and BMI were associated with controlled BP. Another explanation is that northeast Thailand is mainly an agricultural area. As a result, the patients with hypertension in this area are agriculturists; moreover, traditional dancing and playing of northeastern Thai games creates more physical activities. More physical activities can decrease both systolic and diastolic BP including decreased risks for high BP [22, 23]. Our study has shown that hypertensive patients receiving medical treatment at middle level hospitals and standard/advanced level hospitals tended to indicate a higher prevalence of uncontrolled hypertension compared with those at first level hospitals. Similarly, one related study in Kenya illustrated that hypertensive patients in provincial hospitals could control their BP more effectively than those in national hospitals [24]. Patients with uncontrolled hypertension in first level hospitals may be referred to high potential hospitals for proper medical management. Consequently, high level hospitals are permeated with hypertensive patients with poorly controlled BP.

The study reported hypertensive patients with diabetes comorbidity were associated with BP control. This result was similar to that of related studies in Europe [25, 26], showing that diabetes was associated with a high risk of poor BP control. This effect may have resulted from insulin resistance and endothelial dysfunction; thus, increasing BP [27-29]. Several studies reported similar results with this study revealing a relationship between BMI and controlled BP [30-33]. The study found that patients with hypertension presenting BMI more than $25 \mathrm{~kg} / \mathrm{m}^{2}$ tended to be higher at risk of uncontrolled BP. Notably, patients with $\mathrm{BMI}>35 \mathrm{~kg} / \mathrm{m}^{2}$ were 1.7 times at higher 
Table 3 Multivariate analysis for factors associated with uncontrolled hypertension among Thai adults with hypertension

\begin{tabular}{|c|c|c|c|}
\hline Variables & $\begin{array}{l}\text { Adjusted } \\
\text { odds ratio }\end{array}$ & $95 \% \mathrm{Cl}$ & $p$-value \\
\hline \multicolumn{4}{|l|}{ Gender } \\
\hline Female & 1 & & \\
\hline Male & 1.16 & $(1.10-1.20)$ & $<0.001$ \\
\hline Age (years) & 0.97 & $(0.97-0.97)$ & $<0.001$ \\
\hline \multicolumn{4}{|l|}{ Region } \\
\hline Northeast & 1 & & \\
\hline Northern & 1.21 & $(1.14-1.29)$ & $<0.001$ \\
\hline Central & 1.20 & $(1.13-1.28)$ & $<0.001$ \\
\hline Southern & 1.48 & $(1.38-1.59)$ & $<0.001$ \\
\hline \multicolumn{4}{|l|}{ Hospital level } \\
\hline First level & 1 & & \\
\hline Middle level & 1.23 & $(1.16-1.30)$ & $<0.001$ \\
\hline Standard/advance level & 1.12 & $(1.03-1.22)$ & 0.009 \\
\hline \multicolumn{4}{|l|}{ Diabetes mellitus } \\
\hline No & 1 & & \\
\hline Yes & 1.16 & $(1.08-1.23)$ & $<0.001$ \\
\hline \multicolumn{4}{|l|}{ Smoking } \\
\hline Never & 1 & & \\
\hline Ex-smoker & 1.04 & $(0.96-1.11)$ & 0.334 \\
\hline Current smoker & 1.08 & $(0.97-1.19)$ & 0.155 \\
\hline Duration of hypertension (years) & 1.00 & $(0.99-1.01)$ & 0.120 \\
\hline \multicolumn{4}{|l|}{ BMI $\left(\mathrm{kg} / \mathrm{m}^{2}\right)$} \\
\hline$<25$ & 1 & & \\
\hline $25-29.99$ & 1.19 & $(1.13-1.24)$ & $<0.001$ \\
\hline $30-34.99$ & 1.42 & $(1.32-1.52)$ & $<0.001$ \\
\hline$\geq 35$ & 1.70 & $(1.51-1.92)$ & $<0.001$ \\
\hline \multicolumn{4}{|l|}{ LDL (mg/dL) } \\
\hline$<100$ & 1 & & \\
\hline$>100$ & 1.17 & $(1.11-1.22)$ & $<0.001$ \\
\hline \multicolumn{4}{|c|}{ Number of antihypertensive medications } \\
\hline 0 & 1 & & \\
\hline 1 & 1.39 & $(1.13-1.70)$ & 0.002 \\
\hline 2 & 1.80 & $(1.47-2.20)$ & $<0.001$ \\
\hline$\geq 3$ & 2.32 & $(1.89-2.86)$ & $<0.001$ \\
\hline
\end{tabular}

$L D L$ low-density lipoprotein cholesterol, $B M I$ body mass index

Adjusted for gender, age, regions, hospital levels, diabetes comorbidity, smoking status, duration of hypertension, body mass index, LDL level and number of antihypertensive medications

risk when compared with those with $\mathrm{BMI}<25 \mathrm{~kg} / \mathrm{m}^{2}$. This finding could be attributed among most patients with higher BMI defined as obesity. Most patients with obesity have high adiposity levels. The adipocytes are substrate for producing leptin, resulting in increased leptin level, leading to heightened sympathetic nerve activity, contributing to elevated BP [34, 35]. The present study reported that increasing LDL level was associated with uncontrolled hypertension. Our findings agree with related studies [26, 36, 37] supporting the relationship between the cholesterol level and increased BP. Evidence supports the results that LDL cholesterol elevation leads to increased stability of mRNA for AT1 receptors regarding angiotensin II. Moreover, LDL density at vascular level is proportional to cholesterolemia, contributing to vasoconstriction and pressure in response to angiotensin II infusion [38].

Our data showed a relationship between increasing amounts of antihypertensive medications used and uncontrolled BP, firstly, illustrating that other studies reported similar results, followed by various factors [39, 40]. Patients experiencing difficulty controlling BP are likely to be treated with multiple medications. Therefore, this result might be a consequence of uncontrolled hypertension. However, we found that some patients with hypertension without using antihypertensive medication could control their BP.

The strength of this study includes its nationwide scope for uncontrolled hypertension, the largest sample size in Southeast Asia. Thus, the findings of the study could be generalized and applied in similar hypertension populations. One implication of the study is to reduce the prevalence of uncontrolled hypertension, resulting from improving hypertension management. Moreover, hypertensive patients should control their modifiable risk factors. Healthcare services access of hypertensive patients especially at working age should be adjusted for appropriate situations. Above all, MoPH's managers and physicians should provide further preventative strategies to attenuate cardiovascular risk factors.

\section{Limitations}

The study employed a cross-sectional design, and as such, the results could show only factors associated with uncontrolled hypertension. The data presented in the present study were obtained in the 2014 to 2015 Thailand DM/HT of the NHSO from MedResNet central data management, so we were aware of missing data from this observational study. However, this represents a relatively large sample size and some data were missing as from the nationwide observational study, so associations between factors and outcomes could be presented.

\section{Abbreviations}

DM: diabetes mellitus; HT: hypertension; SBP: systolic blood pressure; DBP: diastolic blood pressure; Cl: confidence interval; BMl: body mass index; MoPH: Ministry of Public Health; NHSO: National Health Security Office; SD: standard deviation; GFR_EPI: glomerular infiltration rate calculated by epidemiology collaboration formula; Hb: hemoglobin; Hct: hematocrit; LDL: low density lipoprotein cholesterol; HDL: high density lipoprotein cholesterol; TG: triglyceride; TC: total cholesterol. 


\section{Acknowledgements}

The authors wish to thank the entire staff members of the Department of Military and Community Medicine, Phramongkutklao College of Medicine, for their support in completing this study. The Thai DM/HT study and the Medical Research Network of the Consortium of Thai Medical Schools (MedResNet) were supported by The Thailand National Health Security Office.

\section{Authors' contributions}

BS designed and managed the project, collected and analyzed data and composed the manuscript. RR designed and managed the project and reviewed/ edited the manuscript. AK reviewed/edited the manuscript. MM designed the project and reviewed/edited the manuscript. All the authors participated in approving the final draft of the manuscript. All authors read and approved the final manuscript.

\section{Funding}

No funding was received.

\section{Availability of data and materials}

The datasets generated and/or analyzed during the current study are available at http://www.damus.in.th after the permission of the Thailand DM/HT study of the Medical Research Network of the Consortium of Thai Medical Schools (MedResNet).

\section{Ethics approval and consent to participate}

The data of this study were retrieved from databases: an assessment in Quality of Care among Patients Diagnosed with Type 2 Diabetes and Hypertension Visiting the Ministry of Public Health and Bangkok Metropolitan Administration Hospital in Thailand (Thailand DM/HT) after receiving permission from the Medical Research Network of the Consortium of Thai Medical Schools (MedResNet). The Thailand DM/HT was approved by local institutional review boards of the participating hospitals. The participants provided written consent in agreement with the WMA Declaration of Helsinki-Ethics principles for medical research involving human subjects. This study was reviewed and approved by the Royal Thai Army Medical Department Institutional Review Board, Reference Number S060h/60_Exp.

\section{Consent for publication}

This manuscript includes details and images not relating to any individual person.

\section{Competing interests}

The authors declare that they have no competing interests.

\section{Author details}

${ }^{1}$ Department of Military and Community Medicine, Phramongkutklao College of Medicine, Bangkok 10400, Thailand. ${ }^{2}$ Department of Pharmacology, Phramongkutklao College of Medicine, Bangkok 10400, Thailand.

Received: 4 May 2019 Accepted: 29 June 2019

Published online: 04 July 2019

\section{References}

1. Mills KT, Bundy JD, Kelly TN, Reed JE, Kearney PM, Reynolds K, et al. Global disparities of hypertension prevalence and control: a systematic analysis of population-based studies from 90 countries. Circulation. 2016;134(6):441-50.

2. Aekplakorn W, Sangthong R, Kessomboon P, Putwatana P, Inthawong R, Taneepanichskul S, et al. Changes in prevalence, awareness, treatment and control of hypertension in Thai population, 2004-2009: thai National Health Examination Survey III-IV. J Hypertens. 2012;30(9):1734-42.

3. Wang Z, Chen Z, Zhang L, Wang X, Hao G, Zhang Z, et al. Status of hypertension in China: results from the China hypertension survey, 2012-2015. Circulation. 2018;137(22):2344-56.

4. James PA, Oparil S, Carter BL, Cushman WC, Dennison-Himmelfarb C, Handler J, et al. 2014 Evidence-Based Guideline for the Management of High Blood Pressure in Adults: report From the Panel Members Appointed to the Eighth Joint National Committee (JNC 8)2014 Guideline for Management of High Blood Pressure 2014 Guideline for Management of High Blood Pressure. JAMA. 2014;311(5):507-20.

5. Organization WH. Waist circumference and waist-hip ratio: report of a WHO expert consultation. Geneva. 2008;8-11:2011.

6. Yoon SS, Fryar CD, Carroll MD. Hypertension prevalence and control among adults: United States, 2011-2014: US Department of Health and Human Services, Centers for Disease Control; 2015.

7. Wang J, Zhang L, Wang F, Liu L, Wang H, China National Survey of Chronic Kidney Disease Working G. Prevalence, awareness, treatment, and control of hypertension in China: results from a national survey. Am J Hypertens. 2014;27(11):1355-61.

8. Hu L, Huang X, You C, Li J, Hong K, Li P, et al. Prevalence and risk factors of prehypertension and hypertension in southern China. PLOS ONE. 2017;12(1):e0170238.

9. Meelab S, Bunupuradah I, Suttiruang J, Sakulrojanawong S, Thongkua $\mathrm{N}$, Chantawiboonchai $\mathrm{C}$, et al. Prevalence and associated factors of uncontrolled blood pressure among hypertensive patients in the rural communities in the central areas in Thailand: a cross-sectional study. PLoS ONE. 2019;14(2):e0212572.

10. Hyman DJ, Pavlik VN. Characteristics of patients with uncontrolled hypertension in the United States. N Engl J Med. 2001;345(7):479-86.

11. Peng S, Shen T, Liu J, Tomlinson B, Sun H, Chen X, et al. Uncontrolled hypertension increases with age in an older community-dwelling chinese population in Shanghai. Aging Dis. 2017;8(5):558-69.

12. Khanam MA, Lindeboom W, Razzaque A, Niessen L, Smith W, Milton $\mathrm{AH}$. Undiagnosed and uncontrolled hypertension among the adults in rural Bangladesh: findings from a community-based study. J Hypertens. 2015;33(12):2399-406.

13. Egan BM, Zhao Y, Axon RN, Brzezinski WA, Ferdinand KC. Uncontrolled and apparent treatment resistant hypertension in the United States, 1988 to 2008. Circulation. 2011;124(9):1046-58.

14. Khosravi A, Pourheidar B, Roohafza H, Moezzi M, Mousavi M, Hajiannejad A, et al. Evaluating factors associated with uncontrolled hypertension: Isfahan cohort study, Iran. ARYA Atheroscler. 2014;10(6):311-8.

15. Gu D, Reynolds K, Wu X, Chen J, Duan X, Muntner P, et al. Prevalence, awareness, treatment, and control of hypertension in china. Hypertension (Dallas, Tex: 1979). 2002;40(6):920-7.

16. Sandberg K, Ji H. Sex differences in primary hypertension. Biol Sex Diff. 2012;3(1):7.

17. Danser AH, Derkx FH, Schalekamp MA, Hense HW, Riegger GA, Schunkert $H$. Determinants of interindividual variation of renin and prorenin concentrations: evidence for a sexual dimorphism of (pro)renin levels in humans. J Hypertens. 1998;16(6):853-62.

18. Hicks LS, Fairchild DG, Horng MS, Orav EJ, Bates DW, Ayanian JZ. Determinants of JNC VI guideline adherence, intensity of drug therapy, and blood pressure control by race and ethnicity. Hypertension (Dallas, Tex: 1979). 2004;44(4):429-34.

19. Streppel MT, Arends LR, van Veer P, Grobbee DE, Geleijnse JM. Dietary fiber and blood pressure: a meta-analysis of randomized placebo-controlled trials. Arch Intern Med. 2005;165(2):150-6.

20. Whelton SP, Hyre AD, Pedersen B, Yi Y, Whelton PK, He J. Effect of dietary fiber intake on blood pressure: a meta-analysis of randomized, controlled clinical trials. J Hypertens. 2005:23(3):475-81.

21. Morenga LT, Williams S, Brown R, Mann J. Effect of a relatively highprotein, high-fiber diet on body composition and metabolic risk factors in overweight women. Eur J Clin Nutr. 2010;64(11):1323-31.

22. Bento VF, Albino FB, Moura KF, Maftum GJ, Santos Mde C, Guarita-Souza LC, et al. Impact of physical activity interventions on blood pressure in Brazilian populations. Arq Bras Cardiol. 2015;105(3):301-8.

23. Huai $P$, Xun H, Reilly KH, Wang Y, Ma W, Xi B. Physical activity and risk of hypertension: a meta-analysis of prospective cohort studies. Hypertension (Dallas, Tex: 1979). 2013;62(6):1021-6.

24. Mutua EM, Gitonga MM, Mbuthia B, Muiruri N, Cheptum JJ, Maingi T. Level of blood pressure control among hypertensive patients on follow-up in a regional referral hospital in Central Kenya. Pan Afr Med J. 2014;18:278.

25. Kjeldsen SE, Naditch-Brule L, Perlini S, Zidek W, Farsang C. Increased prevalence of metabolic syndrome in uncontrolled hypertension across Europe: the Global Cardiometabolic Risk Profile in Patients with hypertension disease survey. J Hypertens. 2008;26(10):2064-70. 
26. Cordero A, Bertomeu-Martinez V, Mazon P, Facila L, Bertomeu-Gonzalez $V$, Cosin J, et al. Factors associated with uncontrolled hypertension in patients with and without cardiovascular disease. Rev Esp Cardiol. 2011;64(7):587-93.

27. Yanai H, Tomono Y, Ito K, Furutani N, Yoshida H, Tada N. The underlying mechanisms for development of hypertension in the metabolic syndrome. Nutr J. 2008;7:10

28. Kim JA, Montagnani M, Koh KK, Quon MJ. Reciprocal relationships between insulin resistance and endothelial dysfunction: molecular and pathophysiological mechanisms. Circulation. 2006;113(15):1888-904.

29. Meigs JB, Larson MG, Fox CS, Keaney JF Jr, Vasan RS, Benjamin EJ. Association of oxidative stress, insulin resistance, and diabetes risk phenotypes: the Framingham Offspring Study. Diabetes Care. 2007:30(10):2529-35.

30. Dua S, Bhuker M, Sharma P, Dhall M, Kapoor S. Body mass index relates to blood pressure among adults. N Am J Med Sci. 2014;6(2):89-95.

31. Droyvold WB, Midthjell K, Nilsen TI, Holmen J. Change in body mass index and its impact on blood pressure: a prospective population study. Int J Obes. 2005;29(6):650-5.

32. Chorin E, Hassidim A, Hartal M, Havakuk O, Flint N, Ziv-Baran T, et al. Trends in adolescents obesity and the association between BMI and blood pressure: a cross-sectional study in 714,922 healthy teenagers. Am J Hypertens. 2015;28(9):1157-63.

33. Abebe SM, Berhane Y, Worku A, Getachew A. Prevalence and associated factors of hypertension: a crossectional community based study in northwest ethiopia. PLoS ONE. 2015;10(4):e0125210.

34. Hall JE, Brands MW, Hildebrandt DA, Kuo J, Fitzgerald S. Role of sympathetic nervous system and neuropeptides in obesity hypertension. Braz 」 Med Biol Res. 2000;33(6):605-18.
35. Haynes WG, Morgan DA, Walsh SA, Mark AL, Sivitz WI. Receptormediated regional sympathetic nerve activation by leptin. J Clin Invest. 1997:100(2):270-8.

36. Cicero AF, Rosticci M, Baronio C, Morbini M, Parini A, Grandi E, et al. Serum LDL cholesterol levels and new onset of arterial hypertension: an 8-year follow-up. Eur J Clin Invest. 2014;44(10):926-32.

37. Laaksonen DE, Niskanen L, Nyyssönen K, Lakka TA, Laukkanen JA, Salonen JT. Dyslipidaemia as a predictor of hypertension in middle-aged men. Eur Heart J. 2008:29(20):2561-8.

38. Strehlow K, Wassmann S, Bohm M, Nickenig G. Angiotensin AT1 receptor over-expression in hypercholesterolaemia. Ann Med. 2000;32(6):386-9.

39. Knight EL, Bohn RL, Wang PS, Glynn RJ, Mogun H, Avorn J. Predictors of uncontrolled hypertension in ambulatory patients. Hypertension (Dallas, Tex 1979). 2001:38(4):809-14.

40. Kim KI, Kim Y, Kim HJ, Kang DH, Park JB, Choi DJ, et al. Current status and characteristics of hypertension treatment by primary physicians in Korea: data from Korean epidemiology study on hypertension (KEY study). Am J Hypertens. 2008;21(8):884-9.

\section{Publisher's Note}

Springer Nature remains neutral with regard to jurisdictional claims in published maps and institutional affiliations.
Ready to submit your research? Choose BMC and benefit from:

- fast, convenient online submission

- thorough peer review by experienced researchers in your field

- rapid publication on acceptance

- support for research data, including large and complex data types

- gold Open Access which fosters wider collaboration and increased citations

- maximum visibility for your research: over $100 \mathrm{M}$ website views per year

At BMC, research is always in progress.

Learn more biomedcentral.com/submissions 